This is a preprint of an article published as Alaric Hall, 'Constructing Anglo-Saxon Sanctity: Tradition, Innovation and Saint Guthlac', in Images of Sanctity: Essays in Honour of Gary Dickson, ed. by Debra Higgs Strickland, Visualising the Middle Ages, 1 (Leiden: Brill, 2007), pp. 207-35. The pagination and text of this preprint match those of the final publication. To cite this preprint, please cite the URL $<$ htpp://www.alarichall.org.uk $>$.

\title{
CONSTRUCTING ANGLO-SAXON SANCTITY: TRADITION, INNOVATION AND SAINT GUTHLAC
}

\begin{abstract}
Alaric Hall
"I became a historian," Gary Dickson told me when I met him at a dinner of the Late Antique and Early Medieval Postgraduate Seminar series at the University of Edinburgh, "because I love literature." The desire to analyse texts without having to dismantle one's favourite literature is an understandable one, but Gary's comment was intended to be provocative. This study responds to the provocation by focusing on the cult of the Anglo-Saxon Saint Guthlac, but not on historians' usual preferred source for his life, the Latin Vita Guthlaci. Rather, I focus primarily on the Old English poem, Guthlac A, traditionally viewed as a 'literary' rather than a 'historical' text. I argue that the poem affords insights into Anglo-Saxon constructions of sanctity which are not usually available from the Latin material; most notably, it illuminates ways in which tensions between traditional and Christian notions of ideal male behaviour were constructed and played out in Anglo-Saxon Christian discourses.

Saint Guthlac has enjoyed increasing attention in recent years. He has had some catching up to do: Bede's Historia ecclesiastica gentis Anglorum does not mention him, so it was not until Bede's dominance as the source of choice for eighth-century England was brought seriously into question in the 1980s--coincidentally with the rise of new, more culturally-orientated research questions--that the Latin evidence for Guthlac's life and cult began to enjoy extensive scrutiny. Guthlac was one of Anglo-Saxon England's first homegrown saints, and the focus of considerable textual production. The Vita Guthlaci, composed by one Felix for Ælfwald, king of East Anglia, probably between about 730 and 749, is one of our first Anglo-Saxon saints' lives. ${ }^{1}$ It was translated fairly closely into Old English prose, probably by the early tenth century, and an excerpt was made into a sermon known now as Vercelli Homily
\end{abstract}

1 Felix's Life of Saint Guthlac, ed. and trans. Bertram Colgrave (Cambridge, 1956), pp. 1819. 
$23 .{ }^{2}$ Partly on the strength of this promotion, Guthlac found mention in martyrological and liturgical material. ${ }^{3}$ Chapter 50 of the Vita also formed the basis for an Old English poem known now as Guthlac B, preserved in the Exeter Book (Exeter, Cathedral Library 3501), a collection of Old English poetry from the later tenth century. Sometime between its composition and its inclusion in the Exeter Book, Guthlac $B$ was combined with another poem about Guthlac, which focused on his earlier life, known as Guthlac A. ${ }^{4}$

It is not clear whether Guthlac A shows knowledge of Felix's writing or whether it derives from independent oral traditions, but either way it has generally been viewed by turns to have been composed in a literary medium not conducive to the sober transmission of historical facts, or to be a mere derivative of Felix's Vita, reproducing its evidence at a greater distance from the original events. ${ }^{5}$ But whatever its sources, Guthlac A gives us access to an alternative construction of Guthlac's deeds and significance which is valuable for the history of Anglo-Saxon saints' cults. In particular, the vernacular language and traditional poetic form

2 For editions, see Das angelsächsische Prosa-Leben des hl. Guthlac, ed. Paul Gonser, (Heidelberg, 1909); The Vercelli Homilies and Related Texts, ed. D.G. Scragg, The Early English Text Society 300 (Oxford, 1992), pp. 381-94. On dating, see Jane Roberts, "The Old English Prose Translation of Felix's Vita Sancti Guthlaci," in Studies in Earlier Old English Prose: Sixteen Original Contributions, ed. Paul E. Szarmach (Albany, 1986), pp. 363-79; on the degree of its fidelity, see E. Gordon Whatley, "Lost in Translation:

Omission of Episodes in some Old English Prose Saints' Legends," Anglo-Saxon England 26 (1997), 192-98.

3 See Jane Roberts, "Hagiography and Literature: The Case of Guthlac of Crowland," in Mercia: An Anglo-Saxon Kingdom in Europe, ed. Michelle P. Brown and Carol A. Farr (London, 2001), pp. 77-80, 84-85.

4 All quotations from Old English poetry are based on The Anglo-Saxon Poetic Records: A Collective Edition, ed. George Philip Krapp and Elliott van Kirk Dobbie, 6 vols. (London, 1931-42) (hereafter ASPR); Guthlac A is ASPR 3:49-72. My translations from Guthlac A also make extensive reference to The Guthlac Poems of the Exeter Book, ed. Jane Roberts (Oxford, 1979). A useful literary survey of Guthlac A's purposes and methods is Frances Randall Lipp, "Guthlac A: An Interpretation," Mediaeval Studies 33 (1971), 46-62. Texts from the Exeter Book have been collated with The Exeter Book of Old English Poetry, ed. R.W. Chambers, Max Förster and Robin Flower (London, 1933), and the original punctuation and capitalisation restored. Beowulf has been collated likewise with The Nowell Codex: British Museum Cotton Vitellius A. XV, Second MS, ed. Kemp Malone, Early English Manuscripts in Facsimile 12 (Copenhagen, 1963).

5 Major exceptions are P.W. Conner, "Source Studies, the Old English Guthlac A and the English Benedictine Reformation," Revue Bénédictine 103 (1993), 380-413; Christopher A. Jones, "Envisioning the Cenobium in the Old English Guthlac A," Mediaeval Studies 57 (1995), 259-91. On Guthlac A's sources, see Jane Roberts, "Guthlac A: Sources and Source Hunting," in Medieval English Studies Presented to George Kane, ed. Edward D. Kennedy, Ronald Waldron, and Joseph S. Wittig (Cambridge, 1988), pp. 1-18. 
in which Guthlac A is composed were more conducive than Felix's Latin to expressing distinctively Anglo-Saxon cultural responses to the saint, whereas by contrast, N.J. Higham has noted hints that Felix may not even have been an Anglo-Saxon. ${ }^{6}$ It is also worth noting that Guthlac A may be one of our earliest Old English poems: the text claims that Guthlac "gecostad wearð in gemyndigra monna tidum · ðara pe nu gena ... his wisdomes hlisan healda $\delta$ " ("was tempted in the times of remembering people, those who now yet ... maintain the fame of his wisdom," lines 153-57). Old English poetry usually presents its authority through stock formulas, such as ic gefroegn ("I discovered") and we gehyrdon ("we heard"), so Guthlac A makes a very distinctive claim about its source-value. When Latin hagiography claims to draw on firsthand accounts, this is usually accepted unless there is evidence of mendacity, and there is no reason to suppose that this principle should not apply to Guthlac A. If the poem's claim is true, it was composed during the lifetimes of Guthlac's contemporaries; since Guthlac seems to have died in 714 , the poem would date from the eighth century. ${ }^{7}$ Linguistic evidence for the poem's date is inconclusive, but the eighth century is plausible. ${ }^{8}$ And although the opening of Guthlac $A$ is probably not original to the composition, R.D. Fulk has exposed some of the flaws in recent arguments that Old English poetry tended to be substantially recomposed in scribal transmission, encouraging a prima facie assumption that our manuscript reasonably closely reflects the earliest text. ${ }^{9}$

6 N.J. Higham, "Guthlac's Vita, Mercia and East Anglia in the First Half of the Eighth Century," in Athelbald and Offa: Two Eighth-Century Kings of Mercia: Papers from a Conference Held in Manchester in 2000, ed. David Hill and Margaret Worthington, BAR British Series 383 (Oxford, 2005), p. 85.

7 Conner, "Source Studies," argued that Guthlac A must derive from the period of the Benedictine Reform, but on grounds which strike me as insubstantial: his efforts to reinterpret the lines quoted are both unconvincing and fail to address the key issue. Jones, "Envisioning the Cenobium," p. 268, n. 31, gives an alternative assessment of Conner's analysis.

8 The Guthlac Poems, p. 70; Ashley Crandell Amos, Linguistic Means of Determining the Dates of Old English Literary Texts (Cambridge, Mass., 1980), pp. 35, 76; Peter Clemoes, Interactions of Thought and Language in Old English Poetry (Cambridge, 1995), esp. pp. xii, 19-22, 438-52; R.D. Fulk, A History of Old English Meter (Philadelphia, 1992), p. 400.

9 R.D. Fulk, "On Argumentation in Old English Philology, with Particular Reference to the Editing and Dating of Beowulf," Anglo-Saxon England 32 (2004), 16-25. See also Peter Orton, The Transmission of Old English Poetry (Turnhout, 2000). For the text's putative scribal instability, see especially Roy M. Liuzza, "The Old English Christ and Guthlac: Texts, Manuscripts, and Critics," The Review of English Studies, n.s. 41 (1990), 1-11. The relationship between Guthlac A's opening and the rest of the text is nevertheless tight; see Manish Sharma, "A Reconsideration of the Structure of Guthlac A: The Extremes of Saintliness,” Journal of English and Germanic Philology 101 (2002), 185-200. 
Whereas historians have generally seen Guthlac A as a satellite of Felix's Vita, then, my concern here is to accentuate the texts' considerable differences. Points which have been perceived in the Vita Guthlaci sometimes emerge more clearly and convincingly from Guthlac A. More strikingly, much as Felix's construction of Guthlac drew on other Latin hagiography, I argue that Guthlac A drew on traditional vernacular poetic models. ${ }^{10}$ These models can be inferred from other Old English poetry--here I mainly use Beowulf and The Wife's Lament--by way of comparison with the English material's medieval Scandinavian analogues. ${ }^{11}$ This allows us not only to infer how Guthlac $A$ utilized traditional paradigms, but also to see how it subverted them in order to emphasize the power of Guthlac's Christianity over traditional modes of existence. Insofar as these arguments may encourage a subtler and fuller understanding of Guthlac $A$ as a poem--which I hope they do--this is literary criticism. But such investigation also gives us unique insights into the construction of sanctity and Christianity in vernacular Anglo-Saxon discourse, arguably at a formative period not only of Anglo-Saxon Christianity, but of the Christian cultures which Anglo-Saxons were fostering on the Germanic-speaking continent.

\section{Guthlac's youth}

In Felix's account of Guthlac's youth, Guthlac's time as a warrior is accepted and even praised, a point which has been held to show Felix's syncretism of traditional and Christian ideologies. But Felix also reveals discomfort with Guthlac's military career. He took care to show that Guthlac's hostilities were directed specifically towards "persecutorum suorum adversantiumque sibi hostium famosum excidium" ("the glorious destruction of his persecutors and his adversarial enemies"),

10 Audrey L. Meaney, "Felix's Life of Guthlac: Hagiography and/or Truth,” Proceedings of The Cambridgeshire Antiquarian Society 90 (2001), 29-48; and "Felix's Life of Guthlac: History or Hagiography?" in Hill and Worthington, Ethelbald and Offa, 77-78. For suggestions that Felix was himself influenced by his vernacular context, see Alexandra Hennesey Olsen, "Old English Poetry and Latin Prose: The Reverse Context," Classica et Medievalia: Revue Danoise de Philologie et d'Histoire 34 (1983), 273-82; and Gernot R. Wieland, "Aures lectoris: Orality and Literacy in Felix's Vita Sancti Guthlaci," Journal of Medieval Latin 7 (1997), 168-77.

11 ASPR 4:3-98 (Beowulf); 3:210-11 (The Wife's Lament). 
implying raids directed only at those who threatened him, rather than at indiscriminate sources of wealth. ${ }^{12}$ Moreover, "velut ex divino consilio edoctus tertiam partem adgregatae gazae possidentibus remittebat" ("as though taught by divine counsel, he would return a third share of the collected treasure to the owners"). ${ }^{13}$ Guthlac A's handling of the issue is quite different. The scene which gets Guthlac A's narrative underway, running from line 108, describes Guthlac's youth as a warrior and how an "atela geest" ("loathsome spirit"):

... hyne scyhte pæt he sceaðena gemot nihtes sohte ond purh nepinge wunne æfter worulde swa doð wræcmæcgas pa pe ne bimurnað - monnes feore pæs pe him to honda hupe gelædeð butan hy by reafe rædan motan .
... incited him so that he sought a band of pillagers

by night, and struggled after the worldly through daring, as do exiles/mercenaries, those who do not mourn for the life of a man which brings booty to their hands, as long as they can control the spoil thereby. (lines 127-32)

While Guthlac A, like Felix, avoids making a wholesale attack on traditional heroic social values--in this case by suggesting that Guthlac's band is outside society--it is forthright in characterizing Guthlac as a diabolically inspired criminal. Tellingly, wroecmoecgas (mercenaries/exile-men) occurs three more times in Guthlac A (in lines 231, 263 and 558), invariably denoting the gaestas who beset Guthlac. In lines 114-16, Guthlac abandons his heinous lifestyle specifically by the intervention of an angel struggling with the devil who previously held him:

Tid wæs toweard hine twegen ymb weardas wacedon pa gewin drugon engel dryhtnes ond se atela gæst . the time was nigh--about him, two guardians kept watch--when the angel of the Lord and the terrible demon endured a struggle.

The differences between the approaches to Guthlac's youth in Felix's text and Guthlac A can be understood in terms of differing literary purposes. Felix had been commissioned to write a Vita in praise of Guthlac by Ælfwald, king of East Anglia, presumably as a showpiece whereby Ælfwald could present himself as a patron of the Church, the ruler of the increasingly Latinate kingdom in which Guthlac had

12 Felix, Vita Guthlaci, chap. 18.

13 Ibid., chap. 17. 
lived. ${ }^{14}$ Felix adopted a conventional hagiographical model in which the saint was marked out as such from birth, and as a child was serious and unconcerned with the worldly. ${ }^{15}$ The choice was evidently wise, as this motif was emphasized in later Old English material, but it made Guthlac's military career problematic. ${ }^{16}$ The approach taken by Guthlac A, however, puts a new emphasis on conversion and redemption, perhaps suggesting a more direct role for the text in the discourse of Christian communities. Moreover, the intercessory role of the engel in lines 114-6 recurs numerous times in Guthlac A. ${ }^{17}$ The description of Guthlac's abandonment of his warrior past concludes, in lines 133-35, with:

Swa hy hine trymedon on twa healfa . oppæt pæs gewinnes weoroda dryhten on pæs engles dom ende gereahte ·
Thus, they they strengthened him on the two sides until the lord of hosts ordained the end of that struggle according to the judgement of the angel.

God is distant from these proceedings: although he makes the ultimate decision as to which side should win, that same fact implies that the angel who brings about Guthlac's conversion is acting on his own initiative. Guthlac $A$ does not apparently distinguish between saints and angels--Guthlac himself achieves engelcunde ('angelhood', line 101, cf. 781-82)--so we may consider that here we have the first of many implicit indicators that just as Guthlac was aided by an angel, so may the audience of Guthlac $A$ turn to Guthlac for similar assistance.

But just as Felix modelled his portrayal of Guthlac on other saints' lives, literary models deriving from Old English poetic narratives may have played a part in Guthlac A's handling of Guthlac's warrior past. Our only strong evidence for such traditional narratives is Beowulf. Beowulf has been considered alongside Guthlac A before, but a range of comparisons between the poems have yet to be made. ${ }^{18}$ Thus Beowulf,

14 See also Higham, "Guthlac's Vita."

15 Felix, Vita Guthlaci, chaps. 4-15; cf. Dorothy Ann Bray, A List of Motifs in the Lives of the Early Irish Saints (Helsinki, 1992), pp. 114-15.

16 See Roberts, "Hagiography and Literature," pp. 77-80.

17 See in particular Alexandra Hennessey Olsen, Guthlac of Croyland: A Study of Heroic Hagiography (Washington, D.C., 1981), pp. 27-29; Robin Norris, "The Augustinian Theory of Use and Enjoyment in Guthlac A and B," Neuphilologische Mitteilungen 104 (2003), pp. 171-74; Sharma, “A Reconsideration,” pp. 190-92; and n. 54, below.

18 See for example, Olsen, Guthlac, 25-49; and notes 39 and 44, below. 
too, was unpromising as a youth (lines 2183b-89). ${ }^{19}$ This in itself tells us little, since Beowulf cannot simply be assumed to be representative of Anglo-Saxon tradition. However, several motifs and motif-groups in Beowulf are also common in Old Icelandic sagas, particularly those describing the heroic past prior to the settlement of Iceland (fornaldarsögur), which show that Beowulf was not unique in the literature of northwest European Germanicspeakers--and it is common for saga heroes (like folktale heroes widely) to begin their careers as unpromising youths. ${ }^{20}$ Whereas for Felix, a saint with an unpromising start to his career posed a serious literary problem, for the Guthlac A poet it may have been a bonus. The poet certainly put the idea to good effect: Guthlac $A$ does not simply borrow the motif of the unpromising youth, but inverts it. Normally in Scandinavian material the inactive youth emerges as a heroic warrior; but in Guthlac A, the unpromisingly martial youth becomes a peaceable saint feeding birds from his hands (lines 736-41). The implications of this reading are that Guthlac A engages more intimately with its traditional literary context than has previously been supposed, but also that it subverts the expectations established by this context the more clearly to contrast Guthlac's exemplary Christian life with those of traditional heroes.

\section{Mound-breaking and monster-fighting}

The argument that Guthlac $A$ both draws on and subverts vernacular poetic traditions of heroic narratives can be extended to the saint's encounters with the demons. Numerous commentators have observed that the Vita Guthlaci alters its prime model, Evagrius's Vita Antonii, most notably by making the demons which feature in the Vita more prominent

19 Raymond P. Tripp, Jr. (“Did Beowulf have an Inglorious Youth?" Studia Neophilologica 61 [1989], 129-43) usefully emphasizes the difficulties of this passage, but his unsuccessful search for alternative interpretations serves to underscore the value of the traditional reading.

20 See Inger M. Boberg, Motif-Index of Early Icelandic Literature (Copenhagen, 1966), pp. 100-99; Stith Thompson, Motif-Index of Folk-Literature: A Classification of Narrative Elements in Folktales, Ballads, Myths, Fables, Mediaeval Romances, Exempla, Fabliaux, Jest-Books and Local Legends (rev. ed., 1955-1958; reprint, London, 1966), L100-99. On Beowulf's connections with sagas, see Magnús Fjalldal, The Long Arm of Coincidence: The Frustrated Connection between "Beowulf" and "Grettis saga" (Toronto, 1998). Despite its title, Fjalldal's study provides a useful survey of the texts' similarities. 
and corporeal. ${ }^{21}$ There are also some resemblances between the demons of the Vita and the monsters which Beowulf fights in Denmark. ${ }^{22}$ But Guthlac's struggles with the demons comprise only twenty-four pages out of the one hundred and thirty-two of Bertram Colgrave's edition of the Vita Guthlaci; they are also arguably less ubiquitous than in one of Felix's main models, Evagrius's Vita Antonii. ${ }^{23}$ Guthlac's struggles with demons are merely a prelude to the real substance of the Vita: his miracles. The most dramatic of the struggles--when Guthlac is dragged to the gates of Hell--is rather defused by two further and inevitably anticlimactic demonic assaults. ${ }^{24}$ The traditional-looking characteristics of Felix's Vita appear more convincingly--and suggestively--in Guthlac A. Here, the struggles with the demons comprise almost the whole poem, suggesting an early Christian Anglo-Saxon ideological concern with monsters which is consistent with a range of textual and artistic evidence in the same direction. ${ }^{25}$ Guthlac's miracle-working career is entirely ignored in favour of a narrative focus on his demon-fighting, culminating in the contest at the gates of Hell.

Moreover, although in the Vita Guthlaci, Guthlac's struggles with the demons have important roles, Felix nonetheless makes them an accidental outcome of Guthlac's search for a hermitage in the wilderness. ${ }^{26}$ The motivation of Guthlac A's hero, however, is entirely different (lines 142-49):

21 See for example Benjamin P. Kurtz, From St. Antony to St. Guthlac: A Study in Biography, University of California Publications in Modern Philology 12, pt. 2 (Berkeley, 1926), pp. 103-46 (esp. pp. 109-16); Dorothy Whitelock, The Audience of "Beowulf”' (Oxford, 1951), pp. 80-81; Henry Mayr-Harting, The Coming of Christianity to Anglo-Saxon England, 3d ed. (London, 1991), pp. 229-39; Clemoes, Interactions, pp. 19-22.

22 See Whitelock, The Audience, pp. 80-82.

23 Felix, Felix's Life, pp. 94-117; Katherine O'Brien O'Keeffe, “Guthlac's Crossings," Quaestio: Selected Proceedings of the Cambridge Colloquium in Anglo-Saxon, Norse and Celtic 2 (2001), pp. 8-10.

24 Felix, Vita Guthlaci, chaps. 34, 36. O’Brien O'Keeffe (“Guthlac's Crossings,” p. 22) argued that "unless we are to accuse Felix of a singular ineptitude in his arrangement ... the placing of the visit of the Britons [sic, for a band of Welsh-speaking demons] after the visit to Hell is not bathos. The chapter is, rather, the culmination of the contests for the island." Felix's text is not "singularly inept," but this is not in itself an argument against perceiving an anticlimax.

25 Clemoes, Interactions, pp. 16-22.

26 Cf. O’Brien O’Keeffe, “Guthlac's Crossings.” 
hy him sylf hyra

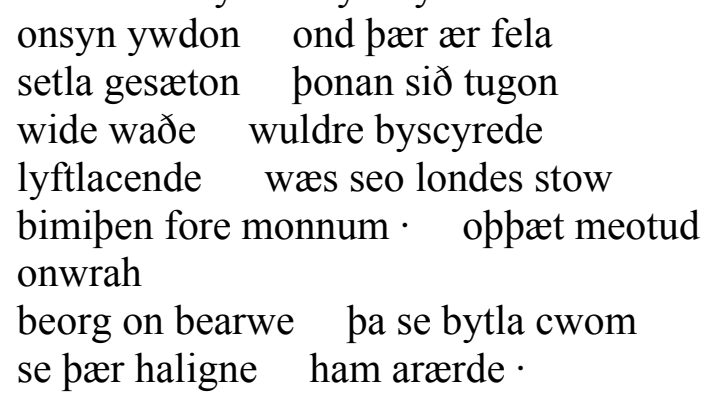

They revealed

their face to him, and there previously settled

many dwelling-places; thence they undertook a journey, with wide wandering, deprived of glory, hovering in the air. That place of the land was

hidden from men until the Measurer revealed

the hill in a grove, when the builder came, he who raised up a holy home there.

Here, Guthlac is an aggressor on a divinely inspired mission to rid remote places of demons and to build a home in them. ${ }^{27}$ The beorg's isolation, and the intimate relationship of the gaestas with the beorg (or here beorgas) is emphasized by the accusation of Guthlac's tormentors that

... he for wlence on westenne beorgas bræce pær hy bidinge earme ondsacan æror mostun æfter tintergum tidum brucan • ðonne hy of wapum • werge cwomon restan rynepragum rowe gefegon wæs him seo gelyfed purh lytel fæc stod seo dygle stow dryhtne in gemyndum idel ond æmen epelriehte feor . bád bisæce betran hyrdes
... for pride he broke mounds/hills in the waste where they, enduring, wretched adversaries, could previously spend time after torments, when they, accursed, came weary from wandering to rest for ?passing periods of time. They enjoyed peace--which was permitted to them for a little while. That hidden place stood in the thoughts of the Lord, idle and uninhabited, far from the law of hereditary land; it awaited the ?claim of a better shepherd. (lines 208-17) 
Guthlac explicitly undertakes a campaign, cleansing one mound after another of its demons, in a divinely directed programme for extending Christian territory into a region which is "epelriehte feor" ("far from the law of hereditary land"). This again has medieval Icelandic parallels, in texts which associate Scandinavia's conversion with the driving of monsters from the land. ${ }^{28}$

Our understanding of the greater belligerence of Guthlac in Guthlac A can be developed through the detail that Guthlac A specifies the location of Guthlac's struggles as a beorg no fewer than fourteen times. As Paul F. Reichardt emphasized when he read Guthlac's beorg as a mountain, beorg's semantic range could be extensive: Anglo-Saxons used it to specify natural mounds, burial mounds, hills, cliffs and mountains. ${ }^{29}$ However, in literature composed in Old English (rather than translated from Latin), and in Old English place-names, burial mounds and small, rounded hills seem the usual denotations. Accordingly, Guthlac B, whose fidelity to the Vita Guthlaci makes its depiction of a tumulus certain, usually uses beorg to specify Guthlac's abode. ${ }^{30}$ Manish Sharma developed Reichardt's points to show that the beorg provides for theologically appropriate images of ascension in Guthlac A. ${ }^{31}$ However, while the ascent of a mountain as a metaphor for saintly progress may be relevant to Guthlac A, the demon-inhabited beorg has closer parallels in the eleventh-century portrayals of Hell by illustrator F of the Anglo-Saxon psalter, Harley 603; and in the copy of The Marvels of the East, Cotton Tiberius B.v, both in the British Library. Sarah Semple has argued that the images in these manuscripts "exemplify a distinctly Anglo-Saxon version of hell and damnation ... It comprises a living-dead existence, trapped within the earth, often within a hollow beneath a hill or mound, tormented by demons." The portrayals are consistent with archaeological evidence for the association of Anglo-Saxon execution burials with burial mounds at

28 See Thomas A. DuBois, Nordic Religions in the Viking Age (Philadelphia, 1999), pp. 8591. Studies on monsters in Old Icelandic literature have otherwise generally looked at monsters from a secular, folkloric perspective; a closer examination of their roles in terms of the histories of Scandinavian conversion in which they so often appear is overdue.

29 Paul F. Reichhardt, "Guthlac A and the Landscape of Spiritual Perfection," Neophilologus 58 (1974), 331-38; cf. The Dictionary of Old English, ed. Angus Cameron, A.C. Amos, and Antonette diPaolo Healey, CD-ROM (Toronto, 1986- ), s.v. beorg.

30 In addition to the Dictionary of Old English, see Margaret Gelling and Ann Cole, The Landscape of Place-Names (Stamford, 2000), pp. 145-52. On the hagiographic conventionality of a tomb as a hermitage, see Meaney, "Felix's Life of Guthlac," p. 80.

31 Sharma, “A Reconsideration,” pp. 194-97. 
marginal points in later Anglo-Saxon landscapes. ${ }^{32}$ While this evidence is mainly later than the composition of Guthlac A, it is not unreasonable to assume that similar ideas circulated earlier, and that the poem drew on them: it, too, depicts demons dwelling in mounds.

It is therefore of interest that the gaestas specify that Guthlac "beorgas brcece". The basic meaning of brecan is 'to break apart or asunder', but it can also mean 'to break into (something), ${ }^{33}$ We have little evidence, archaeological or otherwise, for people breaking into mounds in Anglo-Saxon England; in fact, our main evidence is in Felix's Vita Guthlaci itself, which reads, "erat itaque in praedicta insula tumulus agrestibus glaebis coactervatus, quem olim avari solitudinis frequentatores lucri ergo illic adquirendi defodientes scindebant" ("And there was on the aforementioned island/peninsula a mound brought together with clods from the fields, which greedy visitors of the wilderness once broke open for wealth, digging deep to acquire it"). ${ }^{34}$ The prose Old English translation renders this, "Woes poer in pam sprecenan iglande sum mycel hlow of eorpan geworht, pone ylcan hlcw iu geara men brcecon and dulfon for feos pingum" ("There, on that aforementioned island/peninsula, there was a certain large burial-mound made out of earth; long before, people brcecon and dug into that same mound for items of treasure"); implying that brecan could be used to denote mound-breaking. ${ }^{35}$ This reading is supported by references in

32 Sarah Semple, "Illustrations of Damnation in Late Anglo-Saxon Manuscripts," AngloSaxon England 32 (2003), p. 240. See also Andrew Reynolds, Later Anglo-Saxon England: Life and Landscape (Stroud, 1999), pp. 105-10; and "Burials, Boundaries and Charters in Anglo-Saxon England: A Reassessment," in Burial in Early Medieval England and Wales, ed. Sam Lucy and Andrew Reynolds (London, 2002), pp. 171-94. Semple's analysis relies to some extent on her earlier, "A Fear of the Past: The Place of the Prehistoric Burial Mound in the Ideology of Middle and Later Anglo-Saxon England," World Archaeology 30 (1998-1999), 109-26; which in its handling of literary and onomastic evidence is often inaccurate or credulous, but which in its broad outlines remains convincing. For another assessment of similar material, see Hilda R. Ellis Davidson, "The Hill of the Dragon: Anglo-Saxon Burial Mounds in Literature and Archaeology," Folk-Lore 61 (1950), 169-85.

33 Dictionary of Old English, s.v. brecan section 3a; cf. 3b, 4a, 7.

34 Felix, Vita Guthlaci, chap. 28.

35 Das angelscechsische Prosa-Leben, p. 117. Meaney ("Felix's Life of Guthlac," p. 79) has pointed out that contrary to conventional wisdom, Crowland was not an island but a peninsula. She argued that "on the east, the peninsula ... would have been more easily reached by boat via the River Welland than by land, so that it came to be regarded as an island". A simpler explanation, however, is that both the Old English ig and the AngloLatin term insula used by Felix meant not only 'island' but 'peninsula', as in Bede's comment that "Seloeseu ... dicitur Latine insula uituli marini. Est enim locus undique mari circumdatus praeter ab occidente, unde habet ingressum amplitudinis quasi iactus fundae; qualis locus a Latinis paeninsula, a Grecis solet cherronesos uocari" (Ecclesiastical History 4.13; Bede, Histoire ecclésiastique du peuple Anglais = Historia ecclesiastica gentis Anglorum, 3 vols., ed. and trans. Andre Crépin, et al., Sources chrétiennes 489-491 [Paris, 2005], 2:264-66). 
Old English charter boundary clauses to gebrocene beorgas, as in a well-preserved charter of King Edgar to one Cenwulf, from 961: "of pam slcede on gerihte to brocenan beorge. of pam beorge to wudu forda" ("from that slade to the brocen beorg; from that beorg to woodford"). ${ }^{36}$ Although one might imagine these beorgas not to have been burial mounds, or to have been damaged in some other way (while still remaining distinctive enough to serve as boundary markers), it seems likely that at least some were burial mounds which had visibly been broken into. Although in the Vita Guthlaci Guthlac lives in the tumulus, in Guthlac $A$ he unambiguously builds himself a home upon the beorg, and there is no hint that he breaks into it to live inside. ${ }^{37}$ It seems likely, therefore, that beorgas brcece at least connoted moundbreaking.

As with Guthlac's unpromising youth, this divergence from Felix's account is consistent with the evidence for traditional heroic narratives afforded by Old Icelandic sagas. It is common in sagas for a hero to establish his reputation by breaking into the barrow of a draugr ('undead warrior') and defeating him for his treasure, or otherwise overcoming draugar. ${ }^{38}$ Although Beowulf does not involve any mound-breakings (Beowulf's own intrusion into the world of gaestas being his entry into a mere), it shares sufficient other details with Old Icelandic stories of this kind to show the potential relevance of the Icelandic material to understanding traditional Anglo-Saxon heroic narratives. ${ }^{39}$ While we

36 S 367 in S. E. Kelly, The Electronic Sawyer: An Online Version of the Revised Edition of Sawyer's "Anglo-Saxon Charters", section one [S 1-1602] (British Academy/Royal Historical Society Joint Committee on Anglo-Saxon Charters, 1999), $<$ http://www.trin.cam.ac.uk/chartwww/eSawyer.99/eSawyer2.html > (accessed 6 April 2006); quoted from Cartularium Saxonicum: A Collection of Charters Relating to AngloSaxon History, ed. Walter de Gray Birch, 3 vols. (London, 1885-1893), 3:297. For further examples, see S 254, 360, 411, 443, 596, 1325, 1542 and 1819 (not all of which are independent); cf. Dictionary of Old English, s.vv. brecan, gebrecan. Comparative linguistic evidence for this interpretation is regrettably lacking. The one medieval Germanic language whose literature refers at all often to breaking into burial mounds, Old Icelandic, lacks a cognate of brecan; but it does use its normal word for breaking, the more distantly related brjóta (Ordbog over det norrøne prosasprog/Dictionary of Old Norse Prose [Copenhagen, 1983- ], s.v. §7).

37 Cf. Jones, "Envisioning the Cenobium," pp. 271-79.

38 Boberg, Motif-Index, E461.2; D838.5; cf. E481.3.1. Kathryn Hume, "From Saga to Romance: The Use of Monsters in Old Norse Literature," Studies in Philology 77 (1980), 3-4; Mary Danielli, "Initiation Ceremonial from Norse Literature," Folk-Lore 61 (1945), 229-45; A. Margaret Arent, "The Heroic Pattern: Old Germanic Helmets: Beowulf and Grettis saga," in Old Norse Literature and Mythology: A Symposium, ed. Edgar C. Polomé (Austin, 1969), pp. 130-99.

39 See prominently Danielli, "Initiation Ceremonial"; Andy Orchard, Pride and Prodigies: Studies in the Monsters of the "Beowulf"-Manuscript, rev. ed. (Toronto, 2003), pp. 14071; and Fjalldal, The Long Arm. On gaest in Beowulf and Guthlac A, see Clemoes, Interactions, pp. 439-53. 
cannot be certain, then, it is plausible that stories of heroes making their reputation by entering burial mounds and fighting their inhabitant(s) were traditional in Anglo-Saxon England, and that Guthlac A took up and redeployed the motif.

There is reason, then, to think that Guthlac A's distinctive portrayal of Guthlac's venture into the wilderness as an offensive against the demons which inhabit it draws on traditional heroic narratives. As with Guthlac's inglorious youth, however, it is possible to see traditional narrative patterns not only to have been borrowed, but subverted. ${ }^{40}$ Guthlac is frequently denoted using the extensive Old English poetic lexicon of warriors, but, as Joyce Hill noted, such nouns are rarely used without qualification. ${ }^{41}$ In the same way, comparison between Guthlac A and Beowulf reveals some striking similarities of diction, but also some striking differences. When the gastas describe how Guthlac "beorgas brcece," they specifically portray his motive as wlenco ('pride'), a motivation imputed to Beowulf on his arrival among the Danes when he comes to fight Grendel (line 338). The point of the accusation in Guthlac $A$ is of course that it is slanderous: it serves to demonstrate that in this poem, unlike in the speech of the Danish watchman in Beowulf, wlenco is a negative attribute. By contrast, according to lines 150-51, when Guthlac assaulted the beorg,

Nalæs by he giemde purh gitsunga he did not care at all, through greeds, for lænes lifwelan ac ... gode transient life-fortune, but ... for God.

This for its own part contrasts with the mound-breakings in the Icelandic accounts of young heroes' first great deeds, in which treasure as well as fame is a major attraction. ${ }^{42}$ Likewise, although Beowulf explicitly enters Grendel's mother's mere in pursuit of a feud rather than treasure, treasure is an outcome of the expedition, while by the time of his final fight with the dragon, it is an explicit motivation. ${ }^{43}$ Once more, Guthlac transcends the heroic paradigm.

40 My argument here develops those of Dee Dyas, Images of Faith in English Literature 7001500: An Introduction (London, 1997), pp. 21-26.

41 Joyce Hill, "The Soldier of Christ in Old English Prose and Poetry," Leeds Studies in English, n.s. 12 (1981), 65-69. For learned authorship and audience, see especially Olsen, Guthlac, pp. 15-21.

42 Cf. Hume, "From Saga to Romance," p. 4.

43 Beowulf, lines 2743-51, 2764-6, 3011-15. 
Guthlac A suggests to its audience, then, that Guthlac is like traditional heroes in his deeds, but not in his motivations. He differs also in his methods, defeating his demonic foes not by physical force, but by disputation, invoking God, and holding firm to his faith. ${ }^{44}$ The point is implicit throughout the poem, but is also made explicit in lines 302-5:

no ic eow sweord ongean mid gebolgne hond oðberan pence worulde wæpen ne sceal pes wong gode purh blodgyte gebuen weorðan •
I do not intend to wield a sword against you with an enraged hand, a weapon of the world; this good field must not become inhabited through bloodshed.

Guthlac unambiguously and ostentatiously contrasts his methods with heroic ones. Nor can the implications of his refusal of any "worulde wcepen" ("weapon of the world") be mistaken, since the poem earlier specifies that he fights "mid goestlicum woepnum" ("with spiritual weapons," lines 177-78). As Andy Orchard has emphasized, in Beowulf, gebolgen ('enraged') is applied four times to Beowulf in his monster-fights, and otherwise to his adversaries; it is a characteristic which Guthlac explicitly spurns, but which is applied (in lines 287 and 557) to his demonic adversaries. ${ }^{45}$

That the affinities with heroic narrative structures identified here in Guthlac A were recognized by Anglo-Saxons is suggested by the combination of Guthlac A with Guthlac B in the Exeter Book. Like Beowulf, the pairing of the poems produces a narrative of two sections, the first portraying the monster-fighting which establishes an (unpromising) youth as a hero, the second portraying his last great deed--a structure identical to that of Beowulf. When Margaret E. Goldsmith observed this, she found the similarity so striking that she supposed that Guthlac $A$ and $B$ must have been modelled on Beowulf, a perspective which could be sup-

44 For a recent discussion of Guthlac's use of speech, see Angela Abdou, "Speech and Power in Old English Conversion Narratives," Florilegium, 17 (2000), pp. 204-10. This is not to deny that traditional roots underlie Guthlac A's verbal battle: it may be based on 'flyting' literature suggested by the verbal conflict between Unferth and Beowulf in Beowulf lines 499-606. This interesting possibility, however, does not detract from the didactic significance of Guthlac's refusal of physical battle.

45 Orchard, Pride and Prodigies, p. 32. Margaret E. Goldsmith (The Mode and Meaning of "Beowulf" [London, 1970], p. 258) emphasized these lines, making a similar point. It must be admitted that God is in Genesis A/B (ASPR 1:3-87), lines 54 and 299 described as gebolgen; and in Beowulf, line 2331, Beowulf fears that he has gebulge God; but this does not preclude the argument regarding Guthlac $A$. 
ported by what seems to be an emergent concensus that Beowulf exerted literary influence on other Old English poems (most clearly Andreas). ${ }^{46}$ But the fornaldarsögur suggest that the structure was a traditional one: fornaldarsaga-heroes normally have two major adventures in their careers, one of which establishes their reputation, and the other of which kills them. ${ }^{47}$ Possibly, such a structure is also present within Guthlac A. The assaults of the demons are divided into two main blocks by the respite in lines 323-47, the second being the climactic struggle before the door of Hell. ${ }^{48}$ Most of the resonances with young heroes' monster-fights appear in the first block, while the second section allegorically presents Guthlac's death and rebirth into eternal life, and proceeds to describe his actual ascension to heaven. ${ }^{49}$ However, the two sections are not demarcated by the fitt-markings in the Exeter Book and are none too clearly distinguished. We might ascribe this to the nature of the poet's sources--Guthlac essentially only undertook one great heroic deed, a problem which was only circumvented when Guthlac A was combined with Guthlac B--but the point cannot be pressed.

The contrasting of heroic and holy methods of monster-fighting, emphasizing the superior power of Christian devotion, is not unique to Guthlac A. It is common for dragonfighting saints to rescue "victims who are often described as pagans (or apostate or sceptical Christians)", while at times the saint succeeds where a traditional hero has failed, as in the Vita prima Sancti Carantoci, where Carannog banishes a dragon which King Arthur cannot defeat. ${ }^{50}$ The validity and significance of this kind of comparison is further suggested by Christine Rauer's argument that Beowulf's dragon-fight is modelled on hagiographical ones. ${ }^{51}$ It has long been accepted that the Beowulf-poet expected his audience to know stories besides those told in Beowulf itself and to recall them to deepen

46 Goldsmith, The Mode and Meaning, pp. 257-59; Andy Orchard, A Critical Companion to "Beowulf" (Cambridge, 2003), pp. 163-68.

47 Ruth Righter-Gould, "Fornaldar Sögur Norðurlanda: A Structural Analysis," Scandinavian Studies 52 (1980), 423-41 (esp. pp. 435, 440 n. 23).

48 The division is emphasized by Thomas D. Hill, "The Middle Way: Idel-Wuldor and Egesa in the Old English Guthlac A," The Review of English Studies, n.s. 30 (1979), 182-87.

49 See The Guthlac Poems, pp. 35-36.

50 Christine Rauer, Beowulf and the Dragon: Parallels and Analogues (Cambridge, 2000), p. 71; Vitae sanctorum brittaniae et genealogiae, ed. Arthur W. Wade-Evans (Cardiff, 1944), pp. 145-46; cf. O. J. Padel, Arthur in Medieval Welsh Literature (Cardiff, 2000), pp. 41-42.

51 Rauer, Beowulf and the Dragon, esp. pp. 52-86. 
their appreciation of it. It is now apparent that saints lives could have been among them: the Beowulf-poet, and implicitly his audience, can be expected to have contrasted Beowulf's methods of dragon-fighting with saints' methods--the pagan with the Christian--with important consequences for the poem's meaning. ${ }^{52}$ Beowulf implicitly juxtaposes the efforts of a traditional pagan hero (who does not know the Christian God and must fight with worldly weapons) with saints' lives where, in Rauer's words, "In the great majority of cases the saint inflicts no physical violence on the dragon. More frequently, verbal commands are accompanied by stylized gestures which involve the binding, sending away, locking up, or stylized beating of the dragon." Nor do dragons prove able to fight the saint in any way. ${ }^{53}$ Beowulf's dragon-fight is disastrous for his people, since with his death and the ascendance of Wiglaf, a Swedish invasion of the Geats seems assured. ${ }^{54}$ But the comparison with saints' lives shows that had Beowulf known Christianity, the dragon could have been safely banished, Beowulf succeeding on all fronts. Read either in this hagiographical context, or in the context of Guthlac's own refusal to wield a sword, Beowulf's statement just before he fights the dragon (lines 2518-21) acquires a new undertow:

nolde ic sweord beran wæpen to wyrme gif ic wiste hu wið ðam aglæcean elles meahte · gylpe wiðgripan swa ic gio wið grendle dyde
I would not want to bear a sword, a weapon against the dragon, if I knew how I might otherwise grapple against that awesome creature by my pledge, as I did once against Grendel.

The enlightened audience might hope here for Beowulf's realization, however impracticable, that an alternative paradigm for monster-slaying might exist; instead, however, he disappoints hopes by demonstrating how far his thinking is limited by the traditional paradigm by which he has lived.

Guthlac A and Beowulf, then, can be seen as two sides of the same coin. One is a saint's life which manipulates its traditional medium to contrast the power of the saint as a monster-fighter with the lesser capacity of traditional heroes. The other depicts the pagan, heroic past, using--amongst other things--allusion to saints' lives to show its

52 Ibid., p. 141.

53 Ibid., pp. 70-71.

54 Beowulf, lines 2922-3030. For Wiglaf's inherited involvement in the Swedish-Geatish feud, see lines 2602-27. 
inferiority to the Christian present. Guthlac A shapes this argument to encourage faith in Christian means of facing supernatural threats over traditional ones, specifically consolidating Guthlac's cult. I have already discussed how Guthlac is freed from the clutches of the devil by an angel; his final victory over the demons is won by the protection and intervention of Saint Bartholomew (in Guthlac A, both saint and angel), so that Guthlac himself becomes an angelsaint, with the power to help mortals as he himself was helped. This theme is also emphasized in Vercelli Homily 23, but Guthlac A is able to take the prospect a step further: "swa woes Guðlaces gcest geloeded engla fceðmum" ("Guthlac's spirit was led to the embraces of angels," lines 781-82), we are told, but nine lines later the poem adds that "swa sodfoestra sawla motun..." ("so can the souls of the righteous," line 790). ${ }^{55}$ In this way, Guthlac himself becomes a paradigm for reaching heaven, and implicitly a psychopomp able to extend the chain reaction of salvation to Guthlac A's listeners.

\section{Pagan places?}

I have discussed above the prospect that the beorg in Guthlac A was expected to recall burial mounds, which in Christian Anglo-Saxon worldviews might be inhabited by the damned, and which in traditional culture heroes might break into in search of treasure. In this final section, I develop these observations, drawing this time not on Beowulf, but on The Wife's Lament, which like Guthlac A survives in the Exeter Book. The Wife's Lament has been the subject of extensive debate, and there is much about its interpretation that is in doubt; it has occasionally been set alongside Guthlac A, but never in detail. ${ }^{56}$ Despite the difficulties, comparison of Guthlac A with The Wife's Lament suggests that Guthlac's hermitage had stronger connotations of exile and abandonment than has hitherto been realised. In addition, several scholars have argued that Guthlac A alludes in its portrayal of the beorg to pagan ritual sites.

55 Roberts, "The Old English Prose Translation," pp. 372-75; The Vercelli Homilies, p. 392. 56 See for example Semple, "A Fear of the Past"; and A.N. Doane, "Heathen Form and Christian Function in 'The Wife's Lament'," Mediaeval Studies 28 (1966), 83-84. For a judicious recent survey of opinion, to whose conclusions I largely subscribe, see John D. Niles, "The Problem of the Ending of The Wife's Lament," Speculum 78 (2003), 1107-50 (esp. pp. 1107-12). My own arguments here build on my earlier "The Images and Structure of The Wife's Lament," Leeds Studies in English, n.s. 33 (2002), 1-29 (also available at $<$ http://www.alarichall.org.uk> and <http://eprints.gla.ac.uk/2882/>). 
Clear evidence to support this reading has been lacking, but I suggest that evidence can be adduced on the one hand from The Wife's Lament and its analogues, and on the other from a body of archaeological evidence for late pagan Anglo-Saxon ritual sites which was not available to earlier commentators. ${ }^{57}$ Scepticism about the reading also relates to the later twentieth-century revisionism concerning ill-founded paganizing readings of Christian AngloSaxon texts, epitomized by Eric Gerald Stanley's The Search for Anglo-Saxon Paganism. ${ }^{58}$ This being so, it is worth making two general points before proceeding. Firstly, for Guthlac A to portray Guthlac storming a pagan ritual site and reconsecrating it for Christianity would not in itself be any cause for surprise in a hagiographical work: what would be unusual would merely be that the poem portrays this through allusion rather than explicitly. ${ }^{59}$ Secondly, it is worth emphasizing the surprisingly little-noted fact that Felix explicitly drew on an AngloSaxon source, Cissa, who had still been a pagan during Guthlac's time as an anchorite, and was still alive when Felix wrote Guthlac's Vita. ${ }^{60}$ Although the point is not necessary for my argument, then, it is plausible that Guthlac A's audience knew Anglo-Saxon pagan practices from personal experience or at least contemporary accounts. Guthlac A can be argued to allude to a topos of a pagan place, and again to subvert its traditional handling in order to emphasize Guthlac's power as a Christian saint.

Critics have tended to conflate the setting of Guthlac A with that of Felix's Vita ${ }^{61}$ But as Laurence K. Shook pointed out in 1960, the landscapes depicted in the texts are strikingly different, and I have

57 Karl P. Wentersdorf, “Guthlac A: The Battle for the Beorg,” Neophilologus 62 (1978), 135-42; Davidson, "The Hill of the Dragon," pp. 176-7; cf. Lawrence K. Shook, "The Burial Mound in Guthlac A," Modern Philology 58 (1960), 1-10; Alfred K. Siewers, "Landscapes of Conversion: Guthlac's Mound and Grendel's Mere as Expressions of Anglo-Saxon Nation-Building," Viator 34 (2003), pp. 21-25. Their lack of evidence is emphasized for example by Jane Roberts, "Guthlac A," p. 11.

58 Eric Gerald Stanley, The Search for Anglo-Saxon Paganism (Cambridge, 1975) appeared in its second edition as Imagining the Anglo-Saxon Past: " The Search for Anglo-Saxon Paganism" and "Anglo-Saxon Trial by Jury" (Cambridge, 2000).

59 For examples, see Richard M. Price, "The Holy Man and Christianization from the Apocryphal Apostles to St Stephen of Perm," in The Cult of Saints in Late Antiquity and the Middle Ages: Essays on the Contribution of Peter Brown, ed. James Howard-Johnston and Paul Antony Hayward (Oxford, 1999), pp. 215-38 (esp. pp. 216-23).

60 Felix, Vita Guthlaci, chap. 48; cf. prologue.

61 To cite only a few recent studies: Semple, "A Fear of the Past," 112-13; Jennifer Neville, Representations of the Natural World in Old English Poetry (Cambridge, 1999), p. 44; John Hines, Voices in the Past: English Literature and Archaeology (Cambridge, 2004), p. 62; Siewers, "Landscapes of Conversion," pp. 13-15 (despite the comments on p. 23). 
emphasized above how differently they function. ${ }^{62}$ Felix's Guthlac settles an insula in a fen. But Guthlac A makes no suggestion of a fen--which, as Beowulf shows, was not because Old English poetry was unsuited to describing such landscapes. Indeed, as I have mentioned, Felix's fens resonate with the monster-lairs attested in Beowulf and other vernacular AngloSaxon evidence, making the omission in Guthlac A doubly surprising. ${ }^{63}$ Conversely, Guthlac $A$ twice describes the scene of Guthlac's activity as a "beorg on bearwe" ("beorg in a grove", lines 148, 429). This is paralleled in Felix's text, which mentions that the Fens contain, amongst other things, "crebris insularum nemorumque" ("hills of islands and groves"), and that Guthlac dwelt "inter umbrosa solitudinis nemora solus" ("alone in the shadowy groves of the solitary place"). ${ }^{64}$ But details about landscape are rare in Old English poetry, so Guthlac $A$ 's repeated mention of the beorg on bearwe is more striking than Felix's passing references in a description of the fenland's general character. Guthlac A's landscape is distinctive as Old English poetry, and distinct from Felix's.

So it is of interest that a similar landscape is described in The Wife's Lament. In lines 27-32, what seems certainly to be an exiled female speaker tells us that

heht mec mon wunian on wuda bearwe under actreo in pam eorðscrafe . eald is pes eorðsele eal ic eom oflongad · sindon dena dimme duna uphea bitre burgtunas brerum beweaxne wic wynna leas
A person commended me to dwell in a grove of the woods, under an oak tree, in the earthcave [potentially also 'grave']. This earth-hall is old; I am wholly beset by longing. The valleys are deep, the hills high, bitter/sharp burgtunas overgrown/surrounded with thorny plants: a dwelling without happiness.

The high hills and dim valleys here recall portrayals of Hell and hellish places elsewhere in Old English poetry, and it seems likely that we can read this location as a kind of antiparadise. ${ }^{65}$ Moreover, the speaker adds that she walks alone "under actreo geond pas eorðscrafu" ("under an oak tree, through these earth-caves," line 36). As in Guthlac A, repetition demands attention. The scene in The Wife's Lament bears some close

62 Shook, "The Burial Mound"; cf. Reichardt, "Guthlac A".

63 See notes 20 and 21, above.

64 Felix, Vita Guthlaci, chaps. 24-25.

65 Hall, "The Images," pp. 5-7. 
resemblances to the setting of Guthlac A: the exiled woman is in a cave on wuda bearwe with hellish connotations; Guthlac ascends a mound on bearwe, in which exiled demons live.

Moreover, the speaker's surroundings in The Wife's Lament include burgtunas. Tun's older meaning in English was 'enclosure', which seems more likely here than its later sense 'estate'. Burg normally means 'defended place, town', but imagining the speaker of The Wife's Lament to be surrounded by abandoned towns or fortresses seems rather improbable, and the term has accordingly occasioned much debate. ${ }^{66}$ As I have discussed elsewhere, however, burg was in the late West Saxon dialect of the Exeter Book scribe often confused with beorg--as elsewhere in the Exeter Book in Riddle 27. ${ }^{67}$ Burgtunas thus may be taken to mean 'mound-enclosures' (line 31), in which case the eorðscrcef from which the protagonist of The Wife's Lament speaks is in a beorg. ${ }^{68}$ This meaning seems to me to make better sense than previous suggestions and correlates neatly with another analogue to The Wife's Lament, the right-hand panel of the eighth-century Franks Casket, first adduced by Fiona and Richard Gameson. ${ }^{69}$ The runic inscription on

66 Surveyed by P. R. Orton, “The Wife's Lament and Skirnismál," in Úr Dölum til Dala: Guðbrandur Vigfússon Centenary Essays, ed. Rory McTurk and Andrew Wawn (Leeds, 1989), p. 212.

67 Hall, "The Images," p. 7. Another example, I suggest, is the use of burgscel--ostensibly 'fortress-hall'--of Guthlac's home in Guthlac B, lines 1284 and 1331; which hitherto has also caused critics discomfort: see The Guthlac Poems, p. 57.

68 This being so, one wonders if the beorgtunas might have involved hedges. The statement that the burgtunas are brerum beweaxne is unique in Old English poetry; it has usually been interpreted to mean 'overgrown with briars', implying that the place is neglected and overgrown, the bitre burgtunas accordingly being understood with biter in the wellattested sense of 'bitter, full of grief' (see Hall, "The Images," pp. 5-6, as an example of this reading). But beweaxan and brer are rare in Old English. Beweaxan is as well-attested to mean 'grow around, grow so as to surround' as to mean 'grow over', while Middle English evidence, alongside the Old Irish loan of brer as briar 'pin, brooch(-pin)', supplements Old English hints that brer primarily meant 'any plant that bears prickles or thorns' (Dictionary of Old English, s.vv. be-weaxan, brēr; Middle English Dictionary, ed. Hans Kurath, Sherman M. Kuhn, Robert E. Lewis [Ann Arbor, 1952-2001], $<\mathrm{http}$ :/ets.umdl.umich.edu/m/mec/> (accessed 4 March 2005), s.v. brēr; Colmán Etchingham and Catherine N. Swift, "English and Pictish Terms for Brooch in an EighthCentury Irish Law-Text," Medieval Archaeology 48 [2004], 34-35). Taking biter in its sense 'sharp' (in which it is used, for example, of knives), bitre burgtunas brerum beweaxne might be interpreted better as 'sharp mound-enclosures, topped/surrounded with thorny plants'.

69 Fiona Gameson and Richard Gameson, "Wulf and Eadwacer, The Wife's Lament, and the Discovery of the Individual in Old English Verse," in Studies in English Language and Literature: Papers in Honour of E. G. Stanley, ed. M. J. Toswell and E. M. Tyler (London, 1996), p. 466. 
this panel describes a woman in exile "on harmberga".$^{70}$ This has generally been understood to mean 'on a grief-mound', but I have argued on the basis of the image carved on the panel that the woman is 'in a grief-mound'. Both this image and a further runic inscription on the panel seem to situate this mound in a $w u d u .^{71}$ These connections point to an Anglo-Saxon literary topos, in existence by the time when Guthlac $A$ was composed, in which an exiled woman is situated in a mound, in a grove. That this putative topos was traditional is hinted by the occurrence of similar depictions in Old Icelandic poetry. ${ }^{72}$

Another hint that there was an Anglo-Saxon poetic topos of banishment to a beorg is afforded by the thirteen-line metrical charm, Against a Wen, added in a late eleventh-century hand to a tenth-century manuscript containing Latin commentaries on the Psalms and Numbers. ${ }^{73}$ Its first seven lines run:

Wenne, wenne, wenchichenne, her ne scealt pu timbrien, ne nenne tun habben, ac bu scealt north eonene to pan nihgan berhge, per pu hauest, ermig, enne broper. He pe sceal legge leaf et heafde. Under fot uolmes, under ueper earnes, under earnes clea, a pu geweornie.
Pimple, pimple, pimple-chick, you mustn't build here, nor have any estate, and you must go away to the nearby beorg: there you have, wretch, a brother. He shall lay a leaf at your head. Under the food of the wolf [reading uolues], under the feather of the eagle, under the eagle's claw, may you dwell for ever more.

The charm concludes by commanding the wen to diminish to nothing, by means of a series of comparisons to ever smaller things. There are various problems of interpretation here. ${ }^{74}$ The reference to the wenchichenne has caused some consternation, but probably because chichen here has been understood as 'chicken', whereas in fact it denoted chicks (of all birds, although mainly of chickens): the point is, therefore, that the wen being addressed, already diminutive, is characterised as no more than a child of a pimple. ${ }^{75}$ This curse is surely humorous to at least a degree: its dramatic invocation of the wen is bathetic; the image of

70 ASPR 6:116.

71 Hall, "The Images," pp. 2-3.

72 Ibid., pp. 9-11.

73 London, British Library, Royal 4 A. xiv; ASPR 6:128.

74 For a survey and references, see M.L. Cameron, Anglo-Saxon Medicine (Cambridge, 1993), p. 156.

75 Dictionary of Old English, s.v. cicen; Middle English Dictionary, s.v. chiken. 
the wenchichenne derisory; and the aside, following from the mention of the berhge, that " $p e r$ pu hauest, ermig, enne broper" presumably draws a familial connection between wen and mound, which if so is comically unfavourable to the smaller party. Even so, the charm is predicated on banishing something to a beorg. There is also a hint that at the mound, the "wenne" is to sit beneath a tree, as must the banished woman in The Wife's Lament, since its brother (presumably the mound) is to lay a leaf at its head. This leaf has caused some perplexity and is, naturally, open to other interpretations: connecting this text with The Wife's Lament may afford an explanation. Either way, Against a Wen affords some support for the existence of a topos shared with The Wife's Lament and the right-hand panel of the Franks Casket. Admittedly, Guthlac A does not situate an oak tree on top of Guthlac's beorg. Since no tree is apparent on the harmberg depicted on the Franks Casket, this is not a cause for concern. However, it is worth noting that when Guthlac first assaulted the beorg, according to lines 176-81,

eadig oretta ondwiges heard gyrede hine georne mid gæstlicum wæpnum wong bletsade him to ætstalle ærest arærde cristes rode pær se cempa oferwon frecnessa fela the blessed warrior, stern in resistance, prepared himself eagerly with spiritual weapons, blessed the plain as a ?station for himself; he first raised the cross of Christ, where that warrior overcame many terrors.

Particularly as roods were often conceived metaphorically as trees in Anglo-Saxon discourse, Guthlac's raising of a cross would paradoxically serve to increase the similarity between the beorg on bearwe and the lonely situation depicted in The Wife's Lament. ${ }^{76}$

If Guthlac A's audience perceived in Guthlac's situation resonances with texts like The Wife's Lament, then a contrast was available to them like that between the exile suffered by such traditional figures as Widsith in Widsith and the voluntary, eremitic exile depicted in The Seafarer. ${ }^{77}$ The speaker of The Wife's Lament is confined to a place of misery, from which she cannot escape and which can, moreover, be read--like Beowulf and the right-hand panel of the Franks Casket--to hold up

76 Jane Roberts and Christian Kay with Lynne Grundy, A Thesaurus of Old English in Two Volumes, 2 vols. (Amsterdam, 2000), <http://libra.englang.arts.gla.ac.uk/oethesaurus> (accessed 11 April 2006), section 16.02.05.11, 'The Cross (As Christian Image)'.

77 ASPR 3:149-53 (Widsith); 143-47 (The Seafarer). 
a distopian image of the pagan past for contrast with the Christian present. ${ }^{78}$ Guthlac, however, chooses to enter a similar situation, and, through his Christian faith, has the power not only to maintain his equanimity, but to transform his circumstances.

This reading can be taken a step further if, in The Wife's Lament, the mound in the grove is a pagan sacred place. Arguably, the poem's speaker declares that she was commanded to "herh-eard niman" ("take up a dwelling at a hearg-place"), hearg being the usual Old English word for a pagan sacred site, etymologically and in place-names denoting hills and rocky outcrops), but the word-division here is disputed and other readings are available. ${ }^{79}$ If we do have a hearg here, it would be consistent with the remote setting of Guthlac $A$ in that David Wilson found that Anglo-Saxon place-names containing hearg tend to be situated several miles from known early routeways, by contrast with the other major type of pagan site identifiable by place-names, those containing weoh, which were usually close to them. ${ }^{80}$ As with readings of Guthlac A's beorg on bearwe as a pagan holy place, one of the reasons why hearg has not always been accepted in The Wife's Lament is doubtless a discomfort with paganizing readings of Old English poetry. But as I have said, it is evident that Anglo-Saxons circulated vernacular texts concerning their pagan past and (implicitly) its meaning in their Christian present: it is not inherently implausible, then, that The Wife's Lament's topos concerned pagan sacred places.

Some support for this reading can be gained from the correlation of the scene in The Wife's Lament with the archaeological, toponymic and textual evidence adduced by John Blair for late pagan Anglo-Saxon ritual sites. Blair argued that around the time of the conversion--when traditional Anglo-Saxon ritual life came under acute pressure to compete with Christian practises--Anglo-Saxons adopted earlier British traditions of monumental building. The most consistent aspect of this which he discovered was the reuse and building of square enclosures, whose purpose was clearly not purely functional. Blair found that "a high proportion of these enclosures were superimposed on prehistoric

78 Besides Hall, “The Images," see especially Niles, "The Problem," esp. pp. 1111-12, and Leslie Webster, "The Iconographic Programme of the Franks Casket," in Northumbria's Golden Age, ed. Jane Hawkes and Susan Mills (Stroud, 1999), pp. 243-44.

79 For a full discussion, see Orton, "The Wife's Lament," p. 209.

80 David Wilson, Anglo-Saxon Paganism (London, 1992), p. 10. 
monuments, normally Bronze Age barrows," and also that they often had an orthostat, or sometimes, it would appear, a tree, on top of them..$^{81}$ Noting the reading of burgtunas as 'mound-enclosures', and the presence of an oak tree on top of the eordscrcef in which the speaker of The Wife's Lament wanders, we may consider the unusual scene of The Wife's Lament to correlate precisely with our archaeological evidence for late pagan Anglo-Saxon ritual sites. Conceivably, The Wife's Lament, and more certainly Guthlac A, derive from a time when such sites were fresh in the Anglo-Saxon cultural memory, but this inference is not necessary to my reading. The literary topos and its meaning could have existed independently of actual practice, and would have been encouraged by the biblical association of pagan shrines with mounds and oaks, most prominently in Ezekiel 6:13.

If the landscape of The Wife's Lament can indeed be understood as a recognizable portrayal of a pagan ritual site, then it might not be an unreasonable stretch to read Guthlac A not only to contrast Guthlac with traditional figures in similar places and circumstances, but to add him implicitly to the range of saints who destroyed pagan holy places. If so, then the emphasis which Guthlac A places on Guthlac's conversion from diabolically-inspired warrior to Christian hermit is implicitly extended to his hermitage: it is not simply a place beyond the rule of men, inhabited by demons, but specifically a place of pagan worship, turned to a place of Christian worship. This reading admittedly prompts the question that if the conversion of a pagan holy place works so well in Guthlac A, then why is it not made explicit? One reasonable response would be that whatever the Guthlac $A$-poet's sources were, they did not actually attest that Guthlac had converted a pagan holy place--certainly the Vita Guthlaci does not. The poet did not wish to make--or could not get away with making--a claim which was known to be false; but by emphasizing certain features of Guthlac's landscape, he was able to connote the conversion of a pagan holy place, and to bring something of the power of that portrayal to his poem.

81 John Blair, "Anglo-Saxon Pagan Shrines and their Prototypes," Anglo-Saxon Studies in Archaeology and History 8 (1995), pp. 2-3. 
Conclusions

By writing a saint's life in traditional English verse, the Guthlac A-poet was by definition entering a discourse characterized by tension between older and newer models of behaviour. I have argued, however, that he rose to this challenge more directly than has been realized. In portraying Guthlac as a holy hero, he both utilized and subverted traditional models of heroic behaviour, attested for us by Beowulf and its Old Icelandic analogues. Unlike Felix, who struggled to reconcile Guthlac's youth as a warrior with his sanctity, the Guthlac A-poet identified a motif common in traditional narratives, of the unpromising youth, and used it to delineate a dramatic conversion in Guthlac's life. This helped to make Guthlac A a text about becoming an ideal Christian rather than about being an ideal Christian, and it helped to establish Guthlac himself as a patron and psychopomp through whose assistance people might achieve the same conversions as he did. But rather than having the unpromising youth gain renown as a warrior, Guthlac $A$ inverted the motif by having him renounce it. Likewise, the Guthlac A-poet seems to have adopted and subverted the idea that a hero should establish his reputation by breaking into a burial mound, defeating its supernatural inhabitant in combat, and winning treasure: Guthlac indeed breaks into a burial mound, in a fashion which is much more belligerent than the establishment of his hermitage in Felix's Vita, but explicitly refuses to fight like a traditional hero. He also eschews treasure-hunting: in Guthlac A, the hero's motivation is rather God's directive that he should rid the mound of its demonic inhabitants. Guthlac A's approach here can be seen as a precise counterpart to Beowulf's dragon-fight, where a traditional hero is arguably implicitly contrasted with dragon-fighting saints; in each case, the spiritual method of monster-fighting is shown to be superior to the heroic. It may also be that the mound where Guthlac faces the demons is intended to recall (poetic representations of) pagan ritual sites, in which case Guthlac is not merely chasing demons from the landscape, but implicitly converting a site from pagan worship to Christian. Either way, however, Guthlac A's landscape recalls that of The Wife's Lament. Once more, the comparison favours Guthlac: he is commanded by God to go to the beorg on bearwe as the speaker of The Wife's Lament is commanded by her hlaford ('husband', but also 'lord') to dwell in a cave (arguably within a beorg) on bearwe. But whereas the protagonist of The Wife's Lament can do little more than bemoan her 
misfortune, Guthlac, through his Christian faith, has the power to amend his situation.

If this reading of Guthlac $A$ is accepted, then a new shaft of light falls on Anglo-Saxon discourses of sanctity, arguably of the eighth century. Guthlac A's concern with the improvement of individual Christians, which has long been noted, can be read to have been embedded in a discourse which responded directly to the tension between Christian and traditional ideals of behaviour, a tension which has been inferred between the lines of Latin texts (as in Bede's silence concerning Saint Wilfrid), but which has rarely been identified as the subject of allusions within a text. It gives us a glimpse of vernacular discourses in which Anglo-Saxons were prepared partly to assimilate saints to traditional, non-Christian paradigms of behaviour, but also to engage with those paradigms to show how Christian, saintly behaviour was eminently more powerful.

\section{BIBLIOGRAPHY}

Abdou, Angela. "Speech and Power in Old English Conversion Narratives." Florigelium 17 (2000), 195-212.

Amos, Ashley Crandell. Linguistic Means of Determining the Dates of Old English Literary Texts. Cambridge, Mass., 1980.

Das angelsächsische Prosa-Leben des hl. Guthlac. Ed. Paul Gonser. Heidelberg, 1909.

The Anglo-Saxon Poetic Records: A Collective Edition. 6 vols. Ed. George Philip Krapp and Elliott van Kirk Dobbie. London, 1931-42.

Arent, A. Margaret. "The Heroic Pattern: Old German Helmets, Beowulf and Grettis saga." In Old Norse Literature and Mythology: A Symposium, ed. Edgar C. Polomé. Austin, 1969.

Bede. Histoire ecclésiastique du peuple Anglais = Historia ecclesiastica gentis Anglorum. 3 vols. Ed. and trans. Andre Crépin, et al. Sources chrétiennes 489-91. Paris, 2005.

Blair, John. "Anglo-Saxon Pagan Shrines and Their Prototypes." Anglo-Saxon Studies in Archaeology and History 8 (1995), 1-28.

Boberg, Inger M. Motif-Index of Early Icelandic Literature. Copenhagen, 1966.

Bray, Dorothy Ann. A List of Motifs in the Lives of the Early Irish Saints. Helsinki, 1992.

Cameron, M.L. Anglo-Saxon Medicine. Cambridge, 1993.

Cartularium Saxonicum: A Collection of Charters Relating to Anglo-Saxon History. 3 vols. Ed. Walter de Gray Birch. London, 1885-1893.

Clemoes, Peter. Interactions of Thought and Language in Old English Poetry. Cambridge, 1995.

Conner, P.W. "Source Studies, the Old English Guthlac A and the English Benedictine Reformation." Revue Bénédictine 103 (1993), 380-413.

Danielli, Mary. "Initiation Ceremonial from Norse Literature." Folk-Lore 61 (1945), 229-45.

The Dictionary of Old English. Ed. Angus Cameron, A.C. Amos, and Antonette diPaolo Healey. CDROM. Toronto, 1986- .

Doane, A.N. "Heathen Form and Christian Function in 'The Wife's Lament'." Mediaeval Studies 28 (1966), 71-91. 
DuBois, Thomas A. Nordic Religions in the Viking Age. Philadelphia, 1999.

Dyas, Dee. Images of Faith in English Literature 700-1500: An Introduction. London, 1997.

Ellis Davidson, Hilda R. "The Hill of the Dragon: Anglo-Saxon Burial Mounds in Literature and Archaeology.” Folk-Lore 61 (1950), 169-85.

Etchingham, Colmán, and Catherine N. Swift. "English and Pictish Terms for Brooch in an Eighth-

Century Irish Law-Text." Medieval Archaeology 48 (2004), 31-49.

The Exeter Book of Old English Poetry. Ed. R.W. Chambers, Max Förster, and Robin Flower. London, 1933.

Felix. Felix's Life of Saint Guthlac. Ed. and trans. Bertram Colgrave. Cambridge, 1956.

Fjalldal, Magnús. The Long Arm of Coincidence: The Frustrated Connection between "Beowulf" and "Grettis saga". Toronto, 1998.

Fulk, R.D. A History of Old English Meter. Philadelphia, 1992.

. "On Argumentation in Old English Philology, with Particular Reference to the Editing and

Dating of Beowulf." Anglo-Saxon England 32 (2004), 1-26.

Gameson, Fiona, and Richard Gameson. "Wulf and Eadwacer, The Wife's Lament, and the Discovery of the Individual in Old English Verse." In Studies in English Language and Literature: Essays in

Honour of E.G. Stanley, ed. M.J. Toswell and E.M. Tyler. London, 1996.

Gelling, Margaret, and Ann Cole. The Landscape of Place-Names. Stamford, 2000.

Goldsmith, Margaret E. The Mode and Meaning of "Beowulf". London, 1970.

The Guthlac Poems of the Exeter Book. Ed. Jane Roberts. Oxford, 1979.

Hall, Alaric. "The Images and Structure of The Wife's Lament." Leeds Studies in English, n.s.33 (2002), 1-29.

Higham, N.J. "Guthlac's Vita, Mercia and East Anglia in the First Half of the Eighth Century." In Hill and Worthington, Ethelbald and Offa.

Hill, David and Margaret Worthington, eds. Ethelbald and Offa: Two Eighth-Century Kings of Mercia: Papers from a Conference held in Manchester in 2000. BAR British Series 383. Oxford, 2005.

Hill, Joyce. "The Soldier of Christ in Old English Prose and Poetry." Leeds Studies in English, n.s. 12 (1981), 57-80.

Hill, Thomas D. "The Middle Way: Idel-Wuldor and Egesa in the Old English Guthlac A." The Review of English Studies, n.s. 30 (1979), 182-87.

Hines, John. Voices in the Past: English Literature and Archaeology. Cambridge, 2004.

Hume, Kathryn. "From Saga to Romance: The Use of Monsters in Old Norse Literature." Studies in Philology 77 (1980), 1-25.

Jones, Christopher A. "Envisioning the Cenobium in the Old English Guthlac A." Mediaeval Studies 57 (1995), 259-91.

Kelly, S.E. The Electronic Sawyer: An Online Version of the Revised Edition of Sawyer's "AngloSaxon Charters", Section One [S 1-1602]. British Academy/Royal Historical Society Joint Committee on Anglo-Saxon Charters, 1999. <http://www.trin.cam.ac.uk/chartwww/eSawyer.99/eSawyer2.html>. Kurtz, Benjamin P. From St. Antony to St. Guthlac: A Study in Biography. University of California Publications in Modern Philology 12, pt. 2. Berkeley, 1926.

Lipp, Frances Randall. “Guthlac A: An Interpretation.” Mediaeval Studies 33 (1971), 46-62.

Liuzza, Roy M. "The Old English Christ and Guthlac: Texts, Manuscripts, and Critics." The Review of English Studies, n.s. 41 (1990), 1-11.

Mayr-Harting, Henry. The Coming of Christianity to Anglo-Saxon England. 3d ed. London, 1991.

Meaney, Audrey L. "Felix's Life of Guthlac: Hagiography and/or Truth." Proceedings of the Cambridgeshire Antiquarian Society 90 (2001), 29-48.

and Offa. "Felix's Life of Guthlac: History or Hagiography?" In Hill and Worthington, AEthelbald 
Middle English Dictionary. Ed. Hans Kurath, Sherman M. Kuhn, and Robert E. Lewis. Ann Arbor, 1952-2001. <http://ets.umdl.umich.edu/m/mec/>.

Neville, Jennifer. Representations of the Natural World in Old English Poetry. Cambridge, 1999.

Niles, John D. "The Problem of the Ending of The Wife's Lament." Speculum 78 (2003), 1107-50.

Norris, Robin. "The Augustinian Theory of Use and Enjoyment in Guthlac A and B."

Neuphilologische Mitteilungen 104 (2003), 159-78.

The Nowell Codex: British Museum Cotton Vitellius A. XV, Second MS. Ed. Kemp Malone. Early

English Manuscripts in Facsimile 12. Copenhagen, 1963.

O'Brien O'Keefe, Katherine. "Guthlac's Crossings." Quaestio: Selected Proceedings of the Cambridge Colloquium in Anglo-Saxon, Norse and Celtic 2 (2001), 1-26.

Olsen, Alexandra Hennessey. Guthlac of Croyland: A Study of Heroic Hagiography. Washington, DC, 1981.

. "Old English Poetry and Latin Prose: The Reverse Context." Classica et Medievalia:

Revue Danoise de Philologie et d'Histoire 34 (1983), 273-82.

Orchard, Andy. A Critical Companion to "Beowulf". Cambridge, 2003.

Toronto, 2003.

Pride and Prodigies: Studies in the Monsters of the "Beowulf"-Manuscript. Rev. ed.

Ordbog over det norrøne prosasprog/ Dictionary of Old Norse Prose. Copenhagen,

1983- .

Orton, P.R. “The Wife's Lament and Skirnismál.” In Úr Dölum til Dala: Guðbrandur Vigfússon

Centenary Essays, ed. Rory McTurk and Andrew Wawn. Leeds, 1989.

The Transmission of Old English Poetry. Turnhout, 2000.

Padel, O.J. Arthur in Medieval Welsh Literature. Cardiff, 2000.

Price, Richard M. "The Holy Man and Christianization from the Apocryphal Apostles to St Stephen of Perm." In The Cult of the Saints in Late Antiquity and the Middle Ages: Essays on the Contribution of Peter Brown, ed. James Howard-Johnston and Paul Antony Hayward. Oxford, 1999.

Rauer, Christine. Beowulf and the Dragon: Parallels and Analogues. Cambridge, 2000.

Reichhardt, Paul F. "Guthlac A and the Landscape of Spiritual Perfection." Neophilologus 58 (1974), 331-38.

Reynolds, Andrew. "Burials, Boundaries and Charters in Anglo-Saxon England: A Reassessment." In Burial in Early Medieval England and Wales, ed. Sam Lucy and Andrew Reynolds. London, 2002. Later Anglo-Saxon England: Life and Landscape. Stroud, 1999.

Righter-Gould, Ruth. "Fornaldar Sögar Norðurlanda: A Structural Analysis." Scandinavian Studies 52 (1980), 423-41.

Roberts, Jane. "Guthlac A: Sources and Source Hunting." In Medieval English Studies Presented to George Kane, ed. Edward D. Kennedy, Ronald Waldron, and Joseph S. Wittig. Cambridge, 1988. "Hagiography and Literature: The Case of Guthlac of Crowland." In Mercia: An Anglo-

Saxon Kingdom in Europe, ed. Michelle P. Brown and Carol A. Farr. London, 2001.

. "The Old English Prose Translation of Felix's Vita Sancti Guthlaci." In Studies in Earlier

Old English Prose: Sixteen Original Contributions, ed. Paul E. Szarmach. Albany, 1986.

Roberts, Jane, and Christian Kay; with Lynne Grundy. A Thesaurus of Old English in

Two Volumes. 2 vols. Amsterdam, 2000. <http://libra.englang.arts.gla.ac.uk/oethesaurus>.

Semple, Sarah. "A Fear of the Past: The Place of the Prehistoric Burial Mound in the Ideology of

Middle and Later Anglo-Saxon England." World Archaeology 30 (1998-1999), 109-26.

"Illustrations of Damnation in Late Anglo-Saxon Manuscripts." Anglo-Saxon England 32

$\overline{(2003), 231-45 .}$ 
Sharma, Manish. "A Reconsideration of the Structure of Guthlac A: The Extremes of Saintliness." Journal of English and Germanic Philology 101 (2002), 185-200.

Shook, Lawrence K. "The Burial Mound in Guthlac A." Modern Philology 58 (1960), 1-10.

Siewers, Alfred K. "Landscapes of Conversion: Guthlac's Mound and Grendel's Mere as Expressions of Anglo-Saxon Nation-Building." Viator 34 (2003), 1-39.

Stanley, Eric Gerald. Imagining the Anglo-Saxon Past: "The Search for Anglo-Saxon Paganism” and "Anglo-Saxon Trial by Jury". Cambridge, 2000. The Search for Anglo-Saxon Paganism. Cambridge, 1975.

Thompson, Stith. Motif-Index of Folk-Literature: A Classification of Narrative Elements in Folktales, Ballads, Myths, Fables, Mediaeval Romances, Exempla, Fabliaux, Jest-Books and Local Legends.

Rev. ed. 1955-1958. Reprint, London, 1966.

Tripp, Raymond P., Jr. “Did Beowulf Have an Inglorious Youth?” Studia Neophilologica 61 (1989), $129-43$.

The Vercelli Homilies and Related Texts. Ed. D.G. Scragg. Early English Text Society 300. Oxford, 1992.

Vita sanctorum brittaniae et geneaologiae. Ed. Arthur W. Wade-Evans. Cardiff, 1944.

Webster, Leslie. "The Iconographic Programme of the Franks Casket.” In Northumbria's Golden Age, ed. Jane Hawkes and Susan Mills. Stroud, 1999.

Wentersdorf, Karl P. "Guthlac A: The Battle for the Beorg." Neophilologus 62 (1978), 135-42.

Whatley, E. Gordon. "Lost in Translation: Omission of Episodes in some Old English Prose Saints' Legends." Anglo-Saxon England 26 (1997), 187-208.

Whitelock, Dorothy. The Audience of "Beowulf". Oxford, 1951.

Wieland, Gernot R. "Aures lectoris: Orality and Literacy in Felix's Vita Sancti Guthlaci." Journal of Medieval Latin 7 (1997), 168-77.

Wilson, David. Anglo-Saxon Paganism. London, 1992. 